\title{
6 Russian Monks in the Dechani Monastery (1902-1914)
}

At the turn of the $19^{\text {th }}$ century, Old Serbia (Kosovo and Metochia), a territory with a mixed Serbian and Albanian population, was one of the most unstable regions in the Balkans. The Serbian Orthodox population had been weakened by the closure of the Pech Patriarchate in 1766. Later, the growth of anti-Christian tendencies in Turkey and rising Albanian nationalism resulted in drastic situations for many Serbian families from Metochia. After the defeat of the Prizren League in 1878, the sultan's policy was aimed at supporting the Albanians against the Serbians, who were regarded as potentially revolutionary. ${ }^{345}$ The 1890 s were a period of anarchy, which increased after the Greek-Turkish War of 1897. In 1898-1899 the Pech League was formed which continued the fight for Albanian autonomy. Austro-Hungary supported Albanian independence, seeing it as a bulwark against the Russian-protected Serbia.

As in other regions of the Ottoman Empire, there were two legal ways to support the nationalistic spirit of the population: by opening schools and strengthening ecclesiastical organization. After signing the consular convention between Serbia and Turkey in 1886 a series of Serbian consulates were opened in Skopje, Thessaloniki, Bitola and Prishtina. Russia also continued its traditional financial and diplomatic support of the Serbians in the ecclesiastical and school realms. With the help of the Russian vice-consul to Prizren, I. S. Iastrebov, the first Serbian theological school in Kosovo was founded in 1871. In the Serbian-Bulgarian conflicts in Macedonia he sided with Serbia. ${ }^{346}$

The only possible way in which Serbia could hope to influence the affairs of the Ottoman Empire was through ecclesiastical avenues. The first step was the election of the Serbian Dionisii Petrovich to the Rashka and Prizren See in 1896; the next was the election of Metropolitan Firmilian in Skopje (1903). Both appointments took place with the active support of the Russian embassy in Constantinople. In 1910 the Metropoly of Veles and Dibra was headed by Varnava Rosich, a former student at St. Petersburg Theological Academy who later became the Serbian patriarch. ${ }^{347}$

345 D. T. Batakovich, Dechansko pitanje (Belgrade, 1989), 20-27.

346 P. Kostich, Prosvetno-kulturni zhivot Srba u Prizrenu i njegovoj okolini XIX i pochetkom XX veka (sa uspomenama pisca) (Skopje, 1933), 43-49; K. N. Christich, Zapisi starog Beogradchanina (Beograd, 1983), 174-178; V. Bovan, Jastrebov u Prizrenu (kulurno-prosvetne prilike u Prizrenu i rad ruskog konsula i. S. Jastrebova u drugoj polovini XIX stolecha) (Prishtinka, 1983). See also: A. M. Selishchev, Slavianskoje naselenie v Albanii (Sofia, 1931); J. K. Bilas, Srpske shkole na Kosovu od 1856 do 1912 godine (Prishtina, 1969).

347 P. Orlovich, Skopal'sko vladichansko pitanje 1897-1902 (Belgrade, 1902); N. Razhnatovich, "Rad vlada Crne Gore i Srbije na postavlanju Srpskih mitropolita u Prizrenu i Skopliu 1890-1902 godine”, Istorijski zapisi 22 (Titograd, 1965) 2: 217-275; M. Vojvodich, Petrogradske godine Stojana Novakovicha (1900-1905) (Belgrade, 2009), 44-49. 
Between 1878 and 1903 Russian influence in Old Serbia waned and Austro-Hungary's influence grew; it occupied Bosnia and Herzegovina. The diplomatic defeat of Russia in Bulgaria resulted in its isolation in the Balkans. Despite the unfavourable political situation, beginning in 1900 Russia again became active in the region. The Russian consuls, A. Mashkov, G. Shcherbina and A. Rostkovskii actively supported the Serbians and defended them from the violation of the Turks.

The Lavra of Dechani, founded in the $14^{\text {th }}$ century, traditionally was one of the national symbols of the Serbian people. By the beginning of the $20^{\text {th }}$ century the monastery suffered from Albanian raids, Turkish military aggression, and poor administration. The abbots expended money for their own needs, and thus, the monastery was on the brink of collapse. The situation became especially difficult after the killing of one of the Albanian leaders, Tsol Sokol, in August 1900. At that time the monastery was occupied by Turkish soldiers and the Albanians repeatedly attacked it. In this critical situation, Metropolitan Nikephor decided to request help from the Russians and to invite Russian monks to live in the monastery for a period of time..$^{348}$

In June 1902 Nikephor, Metropolitan of Rashka and Prizren, sent a letter to the Russian consul to Skadr, G. Shcherbina, stating that he would like to begin negotiations regarding the monastery with the Russian embassy in Constantinople and the patriarchate. At the same time, Nikephor asked the prior of the kellion of St. John Chrysostom on Mt. Athos, Cyril, to find a monk who could serve as abbot in Dechani. The metropolitan hoped to reorganize the monastic life with the help of the Russians, who were known for their discipline, and who also had enough money to pay the debts of the monastery; an important reason for Cyril's effort was the support he hoped to receive from the Russian embassy for the monastery. As for the Russian kelliots from Mt. Athos, they saw such a daughter monastery in the Balkans as an opportunity to relocate from Mt. Athos where their efforts were suppressed by the Greeks. As the Russian vice-consul to Prizren, A. Petriaev reported:

Upon receiving the letter from the metropolitan, Cyril immediately wrote to Arsenii [his representative in Constantinople] to leave without delay for Prizren. He instructed him to arrange with the metropolitan to appoint monks from Mt. Athos to form the brotherhood of Dechani. The metropolitan had to allow them to organize their community according to the rules of Mt. Athos with the right to elect the abbot from within the brotherhood. ${ }^{349}$

348 The history of the so called "Dechani affair" is well documented by papers both from Russian and Serbian archives. In 1910 an article on it was published by the the Serbian consul to Skopie J. Jovanovich: Inostrani [J. M. Jovanovich], Dechansko pitanje (Beograd, 1910). The detailed study of D. Batakovich is based on the materials of Serbian archives (D. T. Batakovich, Dechansko pitanje (Belgrade, 1988)). In this chapter, for the first time the documents from Russian archives are used.

349 A copy of the report of A. M. Petriaev. Prizren, July 28, 1902, № 100, RGIA, f. 797, op. 72, 2 otd. 3 st., d. 26, 1. 61. 
We cannot point out the exact date when negotiations commenced between Nikephor and the Russian monks. However, by May 1902 they were known to the Russian consul to Prizren, A. Beliaev, who described the history of Tsol Sokol, the dire situation of the monastery and spoke about the need to protect it. ${ }^{350}$ On July 27, 1902 Arsenii arrived in Prizren and asked the Russian vice-consul, A. Petriaev for support; the latter advised him not to reveal the reason for his visit to the Serbian community, and to be very cautious in his discussions with the metropolitan; Dechani was in his diocese and he would be the one to permit Russian monks to settle there. Petriaev was convinced that an energetic brotherhood would not only help Orthodoxy in Old Serbia, but it would also help return to Christianity the Serbians who had been islamized in the early $19^{\text {th }}$ century. But he opposed the introduction of the monastic rules of Mt. Athos in Dechani, because they would be met with resistance by the Orthodox population who was used to neither the strictness of Athonite rules nor Russian Orthodoxy. ${ }^{351}$

Arsenii arrived in Pech on September 20. The successor of Petriaev, S. V. Tukholka, reported that the installation of monks from Mt. Athos in Dechani took place without undue difficulties due to the good will of the Serbians and the good relations between Metropolitan Nikephor and Cyril. "It is a very advantageous moment for us, which might not come our way again”, wrote the consul. As on Mt. Athos, the Russian monks would remain Russian citizens in Serbia, which gave the Russian diplomatic representatives the obligation to defend them. ${ }^{352}$ Tukholka also stressed the political benefits for Russia in installing the monks in Dechani. First, it would strengthen the position of Orthodoxy vis-à-vis Catholicism, especially that of Austria. Second, it would help established closer relations between Russia and Old Serbia, and raise the profile of Russia. Third, the consulate could enlist Russian monks to gather political information, and thus follow the example of the Austrian consulate which paid Catholic priests for information gathered. The monks were to arrive in small groups of two or three. It seemed important to initially appoint Russian abbots in other Serbian monasteries as well as the brotherhood was becoming Russian due to the lack of Serbian monks. ${ }^{353}$ So here we see a plan of gradual appropriation by the Russians not only of Dechani, but of other monasteries in Kosovo.

By the beginning of December 1902, after a series of meetings between the metropolitan and the Ottoman authorities, order in the monastery was restored. Meanwhile the Russian monk Arsenii arrived in Dechani to take over the administration of the monastery. ${ }^{354}$ In autumn 1902 negotiations between the metropolitan and Russian

350 Dispatch from May 26, 1902, AVPRI, f. Slavianskij stol (Slavic Department), op. 495, d. 4993, 1l.4-6. 351 RGIA. F. 797, op. 72, 2 otd., 3 st., d. 26, 62. A copy of the report of Petriaev. 28 July 1902: RGIA, f. 796, op. 183, 6 otd. 1 st., 1l. 2-3.

352 Dispatch of November 28, 1902. AVPRI. F. Slavianskij stol, op. 495, d. 4993, 11.20-22.

353 Ibid., 11. 21-22.

354 Secret telegram of S. Tuholka to A. Zinoviev. No. 186, ibid., 23. D T. Batakovich, Dechansko pitanje, 72-74. 
diplomats to determine how Dechani would be handed over to the Russians took place. Neither the metropolitan nor the Serbian consul reported to the Serbian government about it. On December 14, Tukholka sent the text of the agreement (nine items) according to which the monastery was to be transferred to the Russians to the Russian ambassador to Constantinople, Zinoviev. ${ }^{355}$ Tukholka found the terms "suitable in general", and reported on the ongoing negotiations concerning the transferring to the Russians of the monasteries Grachanica and Devich and the patriarchal monastery in Pech, i.e. the most important Serbian monasteries in Kosovo and Metochia. ${ }^{356}$ The official act concerning Dechani was signed on January 14, 1903 and by the end of January the transfer had taken place..$^{357}$

As the stabilization of the finances of the monastery and the regulation of relations with Albanians and Turkish soldiers would be costly, Cyril requested permission from the Russian ambassador to Constantinople to collect money in Russia during a period of three years. ${ }^{358}$ Because Ambassador Zinoviev actively supported the Russian monks, he asked the Russian ministry of foreign affairs for financial support for the monasteries in Serbia from the funds of the Bessarabian estates. He stressed the importance of this for Russian policy as it would convince the Serbs that Russia was actively supporting Serbian interests. ${ }^{359}$ The proposal of Zinoviev was supported by the Synod: on September 24, 1904 Cyril was granted permission to have a permanent representative in Odessa to carry out the affairs of the cell of St. John Chrysostom and the Dechani Monastery. ${ }^{360}$ According to the proposal of the Holy Synod on February 4, 1905, the Foreign Ministry decided to grant Cyril an annual sum of 10,000 rubles from the extra capital of the Bessarabian estates. In exchange the Russian Foreign Ministry demanded that the Serbian government recognize the kellion as a Skete of the Hilandar monastery, on whose lands it was situated. ${ }^{361}$ At the same time the Russian government sent to Metropolitan Nikephor 3,580 golden dinars in gratitude for accepting the Russian monks. ${ }^{362}$

355 S. V. Tuholka to I. A. Zinoviev. 14 December 1902, no. 213, AVPRI, f. Slavianskij stol, op. 495, d. 4993, 11. 26-27. The full text has been published several times. See D. T. Batakovich, Dechansko pitanje, 83.

356 AVPRI. f. Slavianskij stol, op. 495, d. 4993, 1. 25.

357 See the final text: D. T. Batakovich, Dechansko pitanje, 85-86. The Arsenij's Diary: D. Bogdanovich, “Ispisi iz Hilandarskog archiva "Dechanski dnevnici ruskog kalugera”, Hilandarcki zbornik, 7 (Belgrade, 1989): 201.

358 AVPRI. f. Slaviansij stol, op. 495, d. 4993, 11. 49-52.

359 Ibid., 11. 35-42. See also the copy of the proposal of the over- procurator of the Holy Synod of the Russian church S. Lukianov to the Holy Synod, 3 April, 1910, no. 3216, RGIA, f. 797, op. 80, 2otd. 3 st., d. 164, 11. 1-4.

360 K. P. Pobedonoscev to V. N. Lamzdorf. AVPRI. f. Slavianskij stol, op. 495, d. 4993, 1. 170.

361 RGIA. F. 797, op. 80.2 otd. 3 st., d. 164, 1l. 1-2.

362 D. T. Batakovich, Dechansko pitanje, 89. 
Despite this auspicious start, the situation in Kosovo in the first months of 1903 was precarious. In March 1903 the Albanians killed the Russian consul to Mitrovitsa; ${ }^{363}$ massacres of the Serbian population continued. In the first half of 1903, due to the political crisis in Serbia, the government did not actively oppose the Russian initiative but this changed. The six Russian monks who had come to Prizren from Mt. Athos were not sent to Dechani because the metropolitan, pressed by the Serbian government, opposed their placement. The Russian consulate would not impose itself in the support of Orthodoxy, reported Tukholka. ${ }^{364}$ The new Serbian government, instated following a military coup in May, 1903, demanded that additional conditions be met, including that the Russians should leave Dechani as soon as the danger had passed. The Serbian government also offered financial compensation to the monks. P. B. Mansurov, an expert in ecclesiastical affairs in the Russian embassy in Constantinople, proposed that Metropolitan Nikephor, in a new agreement with the Serbian government, should give the Russians another monastery in Old Serbia as compensation for the loss of Dechani. Ambassador Zinoviev added that two or three Russians should be left in Dechani. At first Cyril refused to change the conditions, but later seemed to agree with the proposal of Mansurov. ${ }^{365}$ More intasingent was Varsonofii, the representative of the St. John Chrysostom cell in Constantinople: he insisted on retaining ten to fifteen Russian monks in Dechani for five to six years. As the tension surrounding the Russians continued, Cyril decided to leave for Mt. Athos, but was stopped by the metropolitan and the Serbian representative, Hristich. In August the Russian consul Tukholka came to Dechani to investigate the case. ${ }^{366}$ Tukholka hoped to remove the main opponent of the Russians, Gavrilo Dozhich, a resident monk and Bojko and Tsvetko Stamatovich, Serbian teachers in the monastery. ${ }^{367}$

At the beginning of September 1903, Zinoviev and Gruich, the Russian and Serbian ambassadors respectively, signed an agreement in which Cyril remained abbot, but a Serbian monk was appointed as his assistant; the number of the Russian monks was to be reduced to ten; a school would be opened; both the Russian and the Serbian governments would support the monastery. ${ }^{368}$ A commission was formed to implement this agreement by the Foreign Ministry in Belgrade with Metropolitan Dimitry of Shabac as its head. Its members came to a conclusion that the agreement between the Russians and Nikephor was uncanonical and the Russian monks had to

363 D. T. Batakovich, "Pogibija ruskog konzula G. S. Shcherbine u Mitrovitsi 1903”, Istorijski chasopis, XXXIV (Belgrade, 1988): 309-325; D. Bogdanovich, “Ispisi iz Hilandarskog archiva”: 208-212.

364 AVPRI. f. Slavianskij stol, op. 495, d. 4993, 1l. 32-33.

365 Report of S. V. Tukholka, July 12, 1903, ibid., 1. 64.

366 Report of S. V. Tukholka, August 6, 1903, no. 436, ibid., 1l. 73-74; D. Bogdanovich, "Ispisi iz Hilandarskog archiva": 214-215.

367 S. V. Tukholka to the First Department of the Foreign Ministry, December 22, 1903, no. 653, ibid., 11. $93-94$.

368 D. T. Batakovich, Dechansko pitanje, 98-99. 
leave Dechani immediately. ${ }^{369}$ Tukholka insisted on a more active rebuttal on the part of the Russian diplomatic mission in Belgrade, but Ambassador Muraviev preferred caution. He argued that the Russians had legal rights based on the agreement, and Dechani was on Turkish territory not Serbian. However, the Serbians, defending their national holy place, had a moral claim to it as well. ${ }^{370}$

There were several reasons for the tension in Dechani. First, the Mt. Athos monks viewed Dechani as a Russian monastery and demanded full obedience from the Serbs. Nor did they accept the Serbian ecclesiastical traditions. Furthermore, the strict Mt. Athos rules were rather arduous for the Serbs and Cyril preferred to have Russian rather than Serbian monks to instruct Serbian novitiates. ${ }^{371}$

The Russian Foreign Ministry supposed that it would be possible to fulfill the Serbian requirements (a limited term for the Russian presence in the monastery; the old buildings would be preserved; Serbian customs would be observed) and the Russian mission in Belgrade addressed the Serbian government with the following proposal (April 27, 1904). An appointment of a Serbian abbot could also be accepted if he had only a title, while in fact the monastery was ruled by a Russian abbot. The main goal remained the same-recognizing the St. John Chrysostom cell as a skete. ${ }^{372}$ In his answer Prime Minister N. Pashich stressed that the agreement was uncanonical and illegal because it had been implemented without the approval of the Serbian government and the Hilandar monastery to which the cell belonged. ${ }^{373}$ This answer provoked discontent in the Russian embassy in Constantinople. Zinoviev wrote:

The terms expressed in the Serbian note evince the overmastering prejudice which guides the present Serbian government in its attitude to the participation of the Russian elements in the revival of monastic life in Old Serbia. This prejudice seems to me not completely based in reality. Russia will never be able to replace Serbia as the primary influence in an area so distance from Russia. The monastery will always depend on Serbia; here the Russians can only be allies of the Serbs. ${ }^{374}$

In view of the impossibility of a resolution, S. Tukholka proposed that the Dechani case be considered as a separate one from the Mt. Athos one. ${ }^{375}$ In the second half

369 Ibid., 99-100. Dispatch of Muraviov-Apostol-Korobjin. Belgrade, 5 November 1903. AVPRI. f. Slavianskii stol, op. 495, d. 4993, 84, 11. 87-88.

370 Dispatch of Muraviov, November 19, 1903, no. 104, ibid., 1l. 87-88. Report of I. A. Zinoviev. 20 November /3 December 1903, no. 327, ibid., 11. 90-91.

371 Dispatch of A. Muraviev-Apostol-Korobin. February 11, 1904, no. 16, AVPRI, f. Slaviansii stol, op. 495, d. 4993, 1l. 103-104.

372 A project of the secret letter of K. A. Gubastov, "Report on the Dechani affair", ibid., 1l. 195-200.

373 D. T. Batakovich, Dechansko pitanje, 108-111; copy of the Russian note, April 27: AVPRI, f. Slavianskij stol, op. 495, d. 4993, 1l. 123-124; copy of the Serbian answer 17 May, ibid., 1l. 125-131.

374 Dispatch of I. A. Zinoviev. September 11/24, 1904, no. 227, ibid., 1l. 144-148.

375 Report of S. V. Tukholka, September 3, 1905, ibid., 1. 76. 
of 1905 the situation around Dechani seemed to stabilize because the attacks from the Serbian press subsided as did the pressure from the Serbian government. Cyril built good relations with his assistant, the Serbian abbot Theophil. Serbian chanting was introduced in monastic worship which contributed to better relations with the population. Though in Pech there were still two parties, Russophiles and Serbophiles, Tuholka was confident that at least the first round of conflict surrounding Dechani was resolved and the Russians had come out on top. ${ }^{376}$

Meanwhile the financial situation in the monastery worsened. The huge expenses motivated Cyril to ask the Russian Holy Synod about the possibility of acquiring a house in Odessa. ${ }^{377}$ The Archbishop of Cherson vehemently opposed this and pointed out that such a metochion could create difficulties with the local ecclesiastical authorities nor would it be advantageous due to the distance between Odessa and Old Serbia. As a result the Synod rejected Cyril's request. ${ }^{378}$ The position of the monastery remained precarious; on the one hand, Cyril had to resist Albanian demands and on the other, he had to build good relations with the Serbs of the nearest village. At the same time he requested that the metropolitan grant official permission for the 18 Russians who had arrived in Dechani by June 1906 to be resident. ${ }^{379}$ At the beginning of 1908, Cyril requested the Russian consulate in Prizren to allow him to build a daughter monastery in the Orenburg province in Russia on estate land donated to the St. John Chrysostom kellion by E. V. Slepyh; Cyril planned to initiate monks for Dechani there. ${ }^{380}$ The attempt to organize a Mt. Athos metochion in Russia failed: the Holy Synod refused to allow it. ${ }^{381}$

The diplomatic reports of 1906 reveal Cyril's mismanagement of the affairs of Dechani. in December 1906, the commission, headed by the metropolitan, uncovered a large deficit in the budget of the monastery. He insisted on replacing Cyril. ${ }^{382} \mathrm{On}$ October 16, 1908 Nikephor sent a letter to S. Igumanov, director of the foundation in Belgrade, outlining his opposition to Cyril. On October 17 a commission headed by the rector of Prizren Theological School, D. Kovachevich, was appointed and started its work in Dechani on November 2. As Cyril refused to show them the accounts, the members of the commission wrote to the metropolitan that it was not possible to

376 S. V. Tukholka to The First Department of the Foreign Ministry, January 28, 1906, AVPRI, f. Slavianskij stol, op. 495, d. 4995, 11. 22-24.

377 The Office of the head of the Holy Synod to the Archbishop of Cherson. June 13, 1906, RGIA, f. 797, op. 76.2 otd. 3 st., d. $39,1.1$.

378 Extract from the Resolution of the Holy Synod, February 22/March 14, 1907, no. 1192, ibid., 1. 5.

379 Report of S. V. Tukholka, June 18, 1906, ibid., 1l. 36-37.

380 S. Razumovskii to I. A. Zinoviev, January 15, 1908, no. 9, ibid., 1. 106.

381 Holy Synod to Foreign Ministry, June 28, 1908, no. 5385.

382 Metropolitan Nikephor to the Foreign Ministry of Serbia, August 22/September 4, 1904, AS, f. MID (Foreign Ministry) PPO, 1907, red. 404; D. T. Batakovich, Dechansko pitanje, 145. 
investigate the situation and asked him to initiate a petition among the people to have the Russians removed peacefully. ${ }^{383}$

By the end of 1909 it was apparent that the financial situation of the monastery was threatened. The huge expenses, the reduced financing from the Serbian government and the deduction of the incomes from the metochions resulted in large debts. Answering to the numerous complaints of the Serbian government and after an official note from the Serbian ambassador, the Russian ambassador to Constantinople, Charykov, decided to resolve this long drawn out matter. A special commission headed by N. V. Kokhmaskii started its work in the Russian embassy in Constantinople. Its members were Cyril, S. P. Razumovskii the consul to Prizren, and Kutepov, the third secretary of the embassy. Serbia put forward several proposals for the new agreement: the monks in Dechani would be replaced by other Russian monks according to the recommendations of the Russian diplomacy; their stay in the monastery would be limited; the metropolitan and the Serbian and Russian consuls should administer the monastery; a school for the monks and Serbian children should be opened; the Russian monks should assist in repossessing territory captured by the Albanians. ${ }^{384}$ Ambassador Charykov reported:

From the minutes of the meetings of the commission from November 27 to December 10 last year and from its private report of December 19, without the participation of Cyril ... I have concluded that the difficult situation of the Dechani Monastery can be explained by the financial mismanagement and incapacity of Cyril to deal with such a difficult financial affair. ${ }^{385}$

It was decided that Cyril would not return to Dechani and that Charykov would apply for permission for Cyril to collect money in Russia for one year. Also, the monastery would be loaned a sum from the incomes of the Bessarabian monasteries without interest for 12 years. Charykov wrote, "I completely share the view that the monastery should be returned to the Serbian people, but there is no doubt that the immediate removal of the Russians from the monastery would only result in the final destruction of this historical Serbian holy place.” The commission decided that the money received from Russia would be paid to the monastery in monthly installments by the Prizren consulate upon the receipt of a monthly financial report. The financial assistant of the monastery was to be appointed by the Prizren consulate. The Russian consulate promised to ask the Turkish government for military protection of the monastery. ${ }^{386}$

383 Metr. Nikephor to the Head office of the S. A. Igumanov Foundation, October 16, 1908, AS. MID PPO. red. 512. I.; D. M. Kovachevich to the Head office of S. A. Igumanov Foundation, November 1, 1908, ibid.; D. T. Batakovich, Dechansko pitanje, 147-148.

384 Ibid., 165-166.

385 N. V. Charykov to A. P. Izvolskii (the Russian Minister of Foreign affairs), January 20, 1910, no. 14, AVPRI, f. Slavianskij stol, op. 495, d. 4998, 11. 9-13.

386 Ibid., 11. 11, 14-23. 
Though the decisions of the commission were agreed to by Cyril, his assistant Varsonofii at first refused to agree to the interference of lay authorities in the monastic affairs. He was supported by the metropolitan. ${ }^{387}$ However, their efforts brought no results. As one can notice, Charykov, as well as his predecessor Zinoviev, supposed that the situation would improve with better management. His point of view was not shared by the Russian Foreign Ministry both from a political and an economic point of view. Appointing an employee of the consulate to manage the financial matters would mean that the official administrator of the monastery would be the Russian government, which of course would provoke the Serbs. That is why the Council of Ministers decided that the Russians should leave Dechani immediately, and on March 10, 1910 Charykov received a telegram to that effect. ${ }^{388}$ The telegram also made clear that the debts of the monastery (85,000 rubles) had to be paid. On July 25, 1910 the Russian Holy Synod came to the same conclusion. ${ }^{389}$

Though sending the Russian monks to Dechani was recognized as having been a mistake, an immediate removal of the Russians was considered untimely by both Charykov and the Russian ambassador in Belgrade, Gartwig. ${ }^{390}$ Meanwhile the metropolitan continued to undermine the monks. After an exchange of letters a personal meeting between the consul, Razumovskii, and Nikephor about the metropolitan's actions, prevented an open scandal. As Nikephor had planned the canonical prohibition of the Russians in Dechani and their forced removal by the Turkish soldiers, Razumovskii proposed to the Ministry that Nikephor be recalled to Constantinople by the patriarch and replaced. ${ }^{391}$ Nikephor's opinion that Cyril had to be replaced by another more suitable missionary from Russia was shared by Charykov, but because the Russians were in Dechani for only a limited period of time it seemed senseless to appoint a replacement. ${ }^{392}$ The following year the Russian government paid the debts of the monastery and extended the annual subsidy. ${ }^{393}$ The next Russian consul, S. Zuev, thought there was little purpose to the Russian presence in Dechani and opened negotiations on this subject with Dimitrievich, the rector of the Prizren Theological School. ${ }^{394}$

387 Reports of S. Razumovskii from 24 January 24, February 5, 10, 1910, ibid., 1l. 30-31, 32-35, 36-37. Report of M. Rakich. February 23, 1910, AS, f. MID PPO, II, red. 512.

388 AVPRI. f. Slavianskij stol, op. 495, d. 4998, 1l. 66-67.

389 RGIA. F. 797, op. 80. 2 otd. 3 st., d. 164, 11. The Serbian ambassador to St. Petersburg, D. Popovich reported about the decision of the Council of Ministers about the abandoning of the Dechani Monastery by the Russians: Reports from May 6, 27, 1910. AS. F. MID PPO. II. Red. 512.

390 A secret telegram by N. G. Gartwig. June 6/19, 1910, no. 113, ibid., 1. 105. N. V. Charykov to A. P. Izvolskii. 9 June 1910, no. 115, ibid., 1l. 108-109.

391 Report of S. P. Razumovskii. March 14, 1910, no. 37, AVPRI, f. Slavianskij stol, op. 495, d. 4998, 11. 70-73.

392 Report of N. V. Charykov. March 22/April 4, 1910, no. 46, ibid., 1. 76.

393 N. V. Charukov to S. D. Sazonov, November 3, 1910, no. 247, ibid., 1l. 170-171.

394 S. Zuev to N. V. Charykov. July 26, 1911, no. 195, ibid., no. 39-48. 
As a result of the first Balkan War, Metochia became part of Montenegro. Neither its government, nor Gavriil Dozhich, who became Metropolitan of Pech with Russian support, insisted on the removal of the Russians from Dechani. During the First World War in one of the monastery buildings a hospital for wounded soldiers was organized. In 1915 the monastery was in the Bulgarian occupation zone and in 1916 the Russian monks were interned in a camp for prisoners of war in Hungary. 